\title{
Dimensions of totemic history and its related accessories among the Gumbo-Madyirapazhe clan of Gutu, Zimbabwe.
}

\author{
Gilbert Tarugarira \\ Midlands State University, Zimbabwe \\ tarugarirag@staff.msu.ac.zw
}

\begin{abstract}
Ties of kinship traced through blood (consanguinity) are of fundamental importance to individuals because they enshrine historical content which cannot be ignored. The social recognition of these linkages through totems provides the individual with a blue print of interaction which forms a vital basis for cooperation. This article challenges the so-called irrationality of totemism, taking an uncelebrated dimension of how the practice is crucial for tracing the history of a people and the cementing of domestic social relations. The study explores and traces the history behind toponyms with the intention of showing that totems are a rich heritage as a source of history and social registers through which people can identify themselves. The study has been motivated by the Afrocentricity theory which values preservation of oral history as the natural way of storing information and historical realities in many African societies.
\end{abstract}

Key words: totems, toponyms, oral history, identity and social relations

\section{Introduction}

$\mathrm{T}$ otemism has a wide geographical distribution and reveals variations in the form in which it appears in different parts of the world. Whether matrilineal or patrilineal there are however striking uniformities among people who observe this practice for example the Aborigines of Australia, the Malays and Polynesians, the Indians in America, in India among the non-Ayrian mountain groups of the Himalaya mountains, among the Mongolian races and several African groups. According to Bryant (1949 p.445), the term 'totemism' is said to have derived from an Algonkian root, 'otem', signifying 'family or clan sign' or 'brother-sister kinship'. Frazer (1910) defines totemism as 'an intimate relationship supposed to exist between a group of kindred people on the one hand and a species of natural and artificial objects on the other'. For Foggin (1936 p.64) totemism is an 'intimate relationship believed to exist between an individual group of individuals on the one hand and some animal or species of natural or manufactured object on the other'. 
What comes to light here is the systematic association of groups of people with species of animals (occasionally plants and inanimate objects) being connected with a certain element of social organization. The animal, plant or object as Murray (1935 p.80) observed is honoured and respected by the clan and causes the devotees to believe that they may be assured of special protection and favours. Howell (1949 p.169) established that among 'the Dinka of the White Nile, a Crocodile man would swim fearlessly among his reptilian relatives and a Lion man would sleep in the open while any other man would fear lions and make a barricade of thorn.

The members of a totem clan call themselves by the name of their totem and commonly believe themselves to have actually descended from it. Obviously, there must have been internal motives behind the basis of totemism, anchored on the ideas of animism, (the various beliefs in souls), fetishism (the belief in the power of inanimate objects) and ancestor veneration. To the western mind, totemism showed an immoral background and yet there are other uses of totemic accessories employed in greeting, tracing relationships, expressing thanks, or some kind of congratulation (Roberts 1938 p.47). These phenomena were and are of paramount importance as regards the cultural development of the people, given that they have influenced and still influence certain branches of the life of the people. While making reference to the Karanga of Zimbabwe, Aschwanden (1982 p.106) noted that 'everything that is of importance to the Karanga life is reflected in Karanga totemism'. This article makes an effort to show the primacy of totems and their accessories in tracing the history of a people, and as dominant media through which the social order was interpreted and navigated.

Various theories on the origin of totems have been advanced but their detailed consideration is beyond the scope of this article. Frazer made three different suggestions opining that these might be applicable in different places. One derived group totemism from the belief in individual 'external souls' human souls which might reside in animals. Secondly, that group totems came down from individual guardian spirits which were inherited and so passed on to a widening circle of related descendants. Thirdly, that ceremonies gave a form of totemism growing out of ordinary propitiation of animal spirits resulting in the people denying themselves the eating of that animal. The clan henceforth bears the name of the totem animal or plant which is honoured. Devotees to the same totem would therefore bear a special relationship to one another; strengthening of the conception of unity. According to Comarrof and Comarrof (1992 p.53), in as much as totemism is a primordial fact of social classification, it carries with it the consciousness of identity and distinction.

The Gumbo-Madyirapazhe clan totem is examined with the hope of showing how this embraces the collective expression of their history, dealing with issues of place names as sources of oral history and the recapturing of their prides as enshrined in the sexual dimension of the totem. This focus on the totem and its related accessories not only enriches our knowledge on aspects of the clan's cultural heritage but provides insights on the use of traditional knowledge systems in the management of the environment. 


\section{Oral history, geographic preface and peopling of Gutu.}

In the pre-colonial period the geographical space now referred to as Gutu was more of an 'imagined political community' with a galaxy of politically independent units which were initially not arranged into a single political unit. There were no proper, systematic methods or guiding scientific surveys for demarcating boundaries. As a result, Mountains Rasa, Ziro and Chomfuli and rivers such as Mungezi, Nyazvidzi and Dewure were largely the recognized features marking the fluid and porous boundaries (Chief Gutu 2013). Thus, the area then inhabited by the VaHera-Shava and the vaDuma before the vaRufura invasion encapsulated the regions lying between Shashe and Nyazvidzi rivers, Zvivagwe (now Sebakwe) to Ndanga and the confluence of Dewure and Nyazvidzi rivers fell under the Gutu reserve upon the drawing of boundaries in 1902 (Chief Gutu 2013).

In tracing the Rufura's establishment of Gutu, migrations within the Zimbabwe plateau during the $17^{\text {th }}$ and $18^{\text {th }}$ centuries are significant in that they show the dispersion and settlement of several Karanga groups that came out of the north or east as independent units into the south. According to Beach (1984 p.48), as the Changamire state weakened, Rufura, Ngowa, Bonda, Mhari and many others migrated through the Tokwe and Lundi river systems towards the fringes of the Changamire state and the southeastern lowlands. One of the first and most powerful of the groups to travel to the south in the first half of the $18^{\text {th }}$ century was a section of the Musana Gumbo dynasty of Satwa in the middle Mazoe valley who went to Buhera led by Mahwazhe (Beach 1984 p.10). Historical testimonials dealing with the origins of the Gutu chiefdom have Musana at the head of the Gutu geneaology.The earliest recorded accounts of the Gutu story are those made by J. H. Williams (the Native Commissioner of Gutu from 1897 to 1902) and Kenny (who served as Native Commissioner for Gutu between 1903 and 1904 then 1907 to 1921).

These accounts point to Musana, a place north of Salisbury (Harare), as the original home of the Gumbo-Madyirapazhe lineage. According to N. C Kenny writing in 1903, the sons of Musana, namely Chisvino, Mahwazhe, Nemashakwe, Munyikwa and Nendanga made their way to the south after a quarrel with their father. They arrived at Nyashanu's place in Vuhera (Buhera) where each one of them was given a wife and later made heads of sub-districts (NVG2/1/3-Kenny, Acting NC Gutu to CNC, 5 December 1903). Another version of oral tradition holds that Chisvino, Mahwazhe, Nemashakwe, Munyikwa and Nendanga were sons of Diza also known as Binda (the name from which the current name Bindura was derived) who lived in the country of Musana. His clan name was Gumbo and his chidao was Mukuvapasi.

Seeing that he would never inherit the chieftainship; he left with his followers for a new country and settled in Buhera among Nyashanu's people (Anonymous 1962 p.55). Rufura (also identified as Mahwazhe) is said to have used Buhera to launch military expeditions across the Nyazvidzi River into the Hungwe and Nesongano territories. When Nyashanu took Mahwazhe to the Rozvi Mambo, Mahwazhe carried his quiver of arrows (mijutu yemiseve). When they arrived, guards announced that Nyashanu had 
brought a man with a quiver of arrows. Mahwazhe earned himself the nickname Chinemukutu (a person with quivers of arrows). This name was later contracted and corrupted by the whites to Gutu (Mtetwa 1976). Other oral renditions have it that Binda's son Musana had sons Mahwazhe, Munyikwa, Nemashakwe, Nendanga and Chisvino who migrated from Musana. The route taken by Musana's sons led them through Seke and Mutekedza areas inhabited by people of the Shava totem.

From Mutekedza, they moved first into Marondamashanu and then into Buhera where Mahwazhe married Nyashanu's sister Machivetama (Chief Gutu, 2013). Since Mahwazhe had the intention of taking over Hungwe's (Chasura) country across the Nyazvidzi, he took the vigilant precaution of accepting food away from the dare (Anonymous 1962 p.55). 'Madyirapazhe' (one who eats while outside, away from others) became an accepted greeting for him and thus he acquired a new chidao 'Madyirapazhe' in the place of 'Mukuvapasi.'

Upon entry into the Hungwe-Shiri country of the Maokomavi or Masarirambi chidao, Mahwazhe displayed his hunting skills with his quiver of arrows. He killed a rhinoceros which had harassed the Hungwe people in the Hubvumwe area. Again, Mahwazhe is believed to have earned himself a nickname Chinemukutu, later shortened by the whites to Gutu (Chief Gutu 2013). For executing the herculean task, Mahwazhe was given Hungwe's royal stuff which automatically made him the heir apparent to the throne. Upon the death of Hungwe a succession dispute ensued between Chinemukutu and the Hungwe people. Mahwazhe was assisted by his brothers Nendanga, Nemashakwe and Munyikwa. Mahwazhe is also believed to have had some bome, a charm which made his enemies weak in battle. Upon the defeat of the Hungwe many other surrounding chiefdoms with different totems namely Mukaro, Norupiri, Munyaradzi, Mawere and Chiwara were forced into senior or junior partnerships with Gutu. As such, the principal geneaologies living in Gutu and by virtue of belonging to the Chieftainship lineage (dzinza roushe) are the Gumbo-Madyirapazhe under Paramount Chief Gutu (Mashasha undated).

\section{The Mutupo and Chidao of the VaGutu}

As already indicated, the past about the VaGutu carries many versions. What appear to be the points of convergence for the different versions the mutupo and its chidao given below:

Maita Gumbo, Madyirapazhe, Chaurura weGona.

Chipazhamwongo.Vanopona nekurutsa.Gara ramasango.

Chipauro chamafuta.Godzamuto.Chikodzamhandara. Mhuru

Inobva Gona. Vadyi veboora rechirimo. Vari Ndaumbwe.Vari Hwiru.

Vari Masakanja. Zvomutumbwa mwendo waGutu. Chibva Musana. Gumbo

Mashambadza. Shavahuru yakapambe Gona. Maita Chisema. Mushukuru

Wegonan'ombe. Gumbo mubhadha.Mutangakunwa muviri uinenyota. 
Hekani Gutu ndisengei. Senga nyundwa pane romo neziso. Maita weGona. Chinemukutu. Zvaita Chidonhamuto. Chifuka makono hadzi dzakatseketera. Tevera tsimba mutsvairo wenzira. Vatambi vomuganyiro.

\section{The totem, oral history and identity}

This section proceeds to sketch the history of the Gumbo-Madyirapazhe clan through 'laudatory' names or other toponyms. Toponyms according to Jacobs (1990) are the study of place names, their origins, meaning, use and typology. The main function of place names is to identify and provide guidance of locality. Van Langendock (2001) advances that there are indeed various types of toponyms namely dromonym (the name of transportation route), drynonym (the name of a forest or grove), econym (the name of a village or town), limnonym (the name of a lake or pond), and necronym (the name of a cemetery or burial ground).

According to Pfukwa (1998), a name has a social significance and is part of the identity of the bearer. This means that behind a name there are numerous implications and connotations that define the bearer of the name. Anderson (1981) defined a name as a word or term used for identification of a class or category of things or a single thing, either uniquely or within a given context. A study by Pongweni (1983) on the origin of Shona names and surnames confirmed that naming was indeed circumstantial and meaningful. Names in Shona societies have therefore been used as memory banks and markers of events which remind people about their history. Here, a deduction can be made from the observations by a multitude of writers (Pongweni 1983, Chitando 1998, Koopman 2002 and Makondo 2008, among others) that names are historical, expressive, descriptive statements that sometimes shape relationships.

\section{An analysis of the totem and its chidao}

'Gumbo' is the totem of the VaGutu. Maita is an expression of thanks hence 'Maita Gumbo'. Gumbo means 'leg' and this has been used as a surname by members of the clan. Anthroponomy, a branch of onomastics which deals with personal names, nicknames and surnames confirms that surnames are heritable names binding generations of one family. Those who have adopted surnames like 'Gumbo' and 'Madyira' have passed them on from one generation to the other (Chief Gutu 2013, Chief Chingombe 2013). Even separate sections of a family that have become independent are still united by their totem. Given that totemism is intimately connected with exogamy, people of the Gumbo totem would never marry because their zvidao never differ. Sharing a totem bars sexual relations. As Gelfand (1981) noted, marriage between people with the same totem would be tantamount to incest. 'Gumbo' also carries a secondary meaning 'penis.' Among the Karanga people, as Aschwanden (1982:208) observed, the penis 'is the heart of the man...the bearer of fertility and creator of new life'. 
The Gumbo chidao is Madyirapazhe (They who eat whilst outside). The above discussion of the origins and migration of the Gumbo dynasty has traced different versions of how the chidao Madyirapazhe came about. This however carries another sexual interpretation. According to Chief Chingombe (2013), when the sons of Musana migrated from their place of origin, they were not in the company of any women. They spent many nights in the bush during their flight. In the absence of women, they had to masturbate in order to get sexual gratification, hence kudyira panze (eating while outside).

'Chaurura weGona'; Chaurura became Chief Gutu after Mahwazhe. Chief Chaurura was known for making alliances with chiefdoms who had ruled the land before his lineage conquered it. He married Munyaradzi and Nesongano's daughters. The daughter of Nesongano bore him his two eldest sons Rwodzi and Denhere. WeGona denotes someone who comes from a place known as Gona. 'Gona' is a mountain which was the ancestral burying place, a place where sacrifices were and have been offered suggesting a place of mystery and reverence. According to Chief Gutu (2013), 'gona' also referring to the horn of a large beast which contained poison. The poison was smeared on fruits and other edibles which the Hungwe people consumed. It is strongly believed that the poisoning of fruits is one of the tactics that Mahwazhe used to decimate or vanquish the Hera-Shava, Chasura's Shiri people (the Hungwe) and Nesongano's Shumba group to establish the new Gutu dynasty. The bome or charm in the 'gona' made enemies weak in battle (Chief Gutu 2013). As for the secondary meaning; kuurura (a verb from Chaurura) is piercing especially using a red hot iron rod known as muururo. The penis is the muиruro with which the man breaks a girl's virginity as the 'gumbo' is interred. Chief Chaurura 'pierced' the daughters of Munyaradzi and Nesongano and possibly many others who went unrecorded in history (Gonese 2013).

'Chipazhamwongo' Kupazha is to pass stool violently particularly when one is suffering from a serious diarrhea. During intercourse, the husband releases sperms whose thickness and colour are likened to bone marrow. The white-creamyish colour of the semen is of special significance because white is a sign of joy, rain and fertility of the land (Aschwanden 1982:212). When the Karanga people are investigating cases of sterility, they look at the colour of the seminal fluid. 'Good' semen looks like millet or marrow.

'Vanopona nekurutsa' means those who survive by vomiting. An erect penis can only be placated or put to 'rest' (kuzorora or kupona) upon releasing or discharging semen. When people have sexual intercourse, and the man reaches the climax, he loses his strength when his semen is ejaculated. A man in this condition has 'fallen' ( $a w a)$ from kuwa-meaning to fall because the penis has vomited (kurutsa).

'Gara ramasango' 'Gara' a derivative from 'chikara' refers to a big and deadly beast residing in an inaccessible place or forest (sango). Starr (1996) notes that certain expressions and names describe the nature of available resources, population, hunting 
strategies and the general economy of any area. The migration by the Gumbo people from Musana to their final settlement in Gutu made them traverse thick, impenetrable forests which were infested with dangerous beasts. They traversed the forests and successfully fought away beasts given that hunting was their major preoccupation. No wonder why Mahwazhe moved around with his quiver of arrows. As for the secondary meaning of the statement, the penis is likened to a deadly or savage beast surrounded by the forest (pubic hair) and testicles which are likened to hills (Chief Chingombe 2013). 'Chipauro chamafuta' Kupaura is lessening in quantity while mafuta is oil. This relates to the release of semen during ejaculation.

'Godzamuto' Godza is from kukodza which means to thicken and Muto is soup. The Gumbo people were hunters who always ate a lot of meat. Any form of relish needed to have meat added in order to thicken the soup. This explains why the Gumbo people seem to have an insatiable appetite for meat (Chief Chingombe 2013). On a secondary note, the penis causes the fluid or soup (muto-vaginal fluids) in the woman's vagina to flow as it gets thickened by semen.

In Vari Ndaumbwe, variHwiru, vari Masakanja, 'Ndaumbwe', 'Hwiru,' 'Masakanja' are hill strongholds where the Gumbo temporarily camped enroute from Musana. The Hwiru Mountain (from where the present day Hwiru suburb of Gutu-Mupandawana town got its name) is where the Gumbo sought refuge in their fight against the Hungwe (Chief Gutu 2013). And Chibva Musana (One who came from a place called Musana), Gumbo Mashambadza becomes the leg of the travelling merchant who publicized and brought fame to the clan.

Shavahuru yakapambe Gona: Research by Van der Merwe (1936) on the history of the origin and migration of the Gumbo established that there were the vaShava and vaDuma people who occupied the area lying between the Devuli and Nyazvidzi rivers before the arrival of the VaGutu. Beach (1984) and Mashasha (undated) also concur that before Rufura invaded Gutu, Nesongano and Mukaro had already settled in the area. Upon his arrival, Mahwazhe conquered (kupamba) the area, driving out the original inhabitants. On another note, Shavahuru is the bottle-bush grass which has brazenly conquered the Gona area. The grass resembles the pubic hair growing round the male reproductive organs (Gonese 2013).

Maita Chisema: Chisemo is a splinter of wood that has penetrated flesh. This is again likened to the penis penetrating into the vagina (Chief Chingombe 2013). Mushukuru wegonan'ombe: One who nips violently from the horn of a large beast used as a container usually filled with medicants used by or prescribed by a n'anga. As already alluded to, the same also relates to the charm which Mahwazhe used to weaken his enemies. Secondarily, the expression relates to the penis nipping from the vagina which is indeed full of delicacies (Chief Chingombe 2013). Gumbo mubhadha: The leg, a walking or fighting stick which is likened to an erect penis. 
Mutangakunwa muviri uinenyota: The one who drinks first before the whole body is immersed. The leg is the first to drink from the pool just as it is the penis, the first to penetrate into the vagina. When people are having sexual intercourse, the penetration of the erect penis is indeed the 'drinking'. The male organ penetrates first before the male and female bodies coalesce into a big lump. Just like when a cow goes to the river to drink, she puts one leg in before her mouth touches the water (Aschwanden 1982).

Senga nyundwa pane romo neziso: Nyundwa is the hump on an animal usually a bull. The mouth and eye (romo neziso) describe the anatomy of the male reproductive organ (penis). The impression is that the 'eye' and 'mouth' of the penis are one- the tip which sees its way to the vagina and 'spits' the semen (Gonese 2013).

Maita weGona: An expression of gratitude to the one who hails from Gona or one who possesses some charm in the big horn.

Chinemukutu: The history of the origins and migration of the VaGutu has already touched on how Mahwazhe earned himself the nickname Chinemukutu (a person with quivers of arrows). This name was later contracted and corrupted by the whites to Gutu (Mtetwa 1976). Secondarily, an arrow is the penis.

Zvaita Chidonhamuto: An expression of gratitude to the penis from where soup or semen drips.

Chifukamakono, hadzi dzakatseketera: One who cushions oneself using other huge beasts as cover while females (the hens) are responding to the courtship of the cock. The defeat of the Shiri-Hungwe and vaGarwe by Mahwazhe signaled the beginning of the end for many of the surrounding chiefdoms namely Mukaro, Norupiri, Mawere, Munyaradzi and Chiwara. These were the 'females' (hadzi) who were forced into junior partnerships with Gutu and his powerful followers. Vatambi vomuganyiro: Those who play, dance or take part in some form of entertainment within the mixing bowl of dough. This is likened to the penis in a lubricated vagina.

\section{Other totemic accessories}

Since totem animals were not used as food, their accumulation provided wealth and the supply of food in the form of milk and other products. In a way, totemism was considered as a conservation strategy whose aim was to create a harmonious relationship between people and the natural environment. Chemhuru and Masaka (2010) also noted that totemism was significant in extending some moral consideration to animals, a practice which was believed to promote a virtuous life that fostered a desirable environmental ethic. This explains why the violation of totemism was believed to invite an angry reaction at supernatural level (Tatira 2004). Thus, the bond created by totems among the ancestors, the environment and the people was also a strategy to protect wildlife. According to Kasere (2010), eating one's totem in African cultures is considered a taboo with fatal consequences such as misfortunes, illness, death, falling 
away of a victim's teeth and abject poverty. Thus, a strict application or observation of a totem would help people live at peace with animals and plants. People would therefore not deliberately kill, abuse, and mistreat certain non-human species or plants. The Gumbo people do not consume the leg of any animal. If closely observed, this move would curtail the exploitation and abuse of species from extinction.

Totemism also upholds the idea of collectivism and teamwork. Bullock (1931 p.51) lamented that the disappearance of totemism would sound the death kernel of the bulwarks not only of African custom, but of unhu- the fountain and aura of Shona ethnic life. The Southern Rhodesian Law; the Native Law and Courts Act even recognized totemism as an indicator of African ideas of relationship. This explains why the practice has survived and been of social service as a social bond between members of the same clan towards maintaining its immanent cohesive force with its beneficial social obligations of brotherliness and mutual aid.

The observation of totems bestows obligations of hospitality and mutual aid towards each other, supporting one another in quarrels and offering assistance during times of crisis. Where clans are dispersed over chieftainship boundaries, the tie of clanship which is concretized by the totem may operate to mitigate hostility between adjacent groups. Relationships born of intermarriages implored that the members of a clan may have particular duties to perform in the other clan's rituals. In all groups, membership or closeness to the royal clan would carry some prestige and be the basis for conferring political office (Gluckman 1965p.34). People that came to Mahwazhe's assistance as war collaborators in fighting the Shiri-Hungwe namely Matombo, Soro, Mushangwe and Mhuru, among others, were later rewarded with wives and areas to rule over. The intermarriage cemented relations between the Gumbo people and their neighbours who carried different totems.

\section{Conclusion}

Oral history's importance according to Ranger (1987) has always been undermined by the Europeans who dominated sources such as written sources and archaeology. The examination of the Gumbo totem has demonstrated that recording of people's memories, experiences and opinions is indeed a living history of everyone's unique life experiences and an opportunity for those people who have been hidden from history to have their voices heard. People's hopes, feelings, aspirations, disappointments, family histories and personal experiences can collectively be learnt through oral tradition. For Pikirayi (1993) oral history provides a rich opportunity for human interaction.

Guided by the conviction that the reconstruction of much of Zimbabwe's pre-colonial history has been done through oral sources, history then, was also kept through names. As demonstrated above, toponyms functioned as a memory bank, producing a rich tapestry of historical accounts which continue to be transmitted from one generation to 
the next through word of mouth. While some portions in the totem and its chidao take the form of praise poems, an effort was made to show that they are crucial in promoting the collection, preservation and use of recorded memories for purposes of facilitating and developing the use of oral history.

\section{References}

\section{Archival Files}

NVG 2/1/3 Kenny, Acting NC Gutu to CNC, 5 December 1903.

\section{Interviews}

Paramount Chief Gutu (Edmund Masanganise) 13 July 2013, Gutu.

Chief Chingombe (Virimai Muzondo Rutsate) 15 July 2013, Gutu.

Naison Gonese, 19 July, 2013, Gutu.

\section{Published Primary Sources}

Bullock, C. (1931). 'The Origin and Nature of Totemism' NADA, Vol.9.

Foggin, B. J. M. (1936). 'Totemism' NADA, Vol.14.

Murray, G. S. (1935). 'Totems' NADA, Vol.13.

Roberts, J. C. (1931). 'ChiShona Names', NADA, Vol.9.

Roberts, J. C. (1938). 'Totemism and Sexuality' NADA, Vol.15.

Van Der Merwe, D. J (1936). 'Some History of the Vakaranga in the Gutu Reserve' NADA, Vol.14.

\section{Secondary Sources}

Aschwanden, H. (1982). Symbols of Life: An Analysis of the consciousness of the Karanga, Mambo Press: Gweru.

Bryant, A.T. (1949). The Zulu People: As They Were Before The White Man Came, Shuter and Shooter: Pietermaritzburg.

Chabata, E. (2008). A Reflection of People's Changing Philosophy in changing times, Gweru. Mambo Press.

Comarrof, J. and Comarrof, J. (1992). Ethnography and the Historical Imagination, Oxford: Westview Press.

Beach, D. N (1980). The Shona and Zimbabwe: 900-1850, Gweru: Mambo Press,

Gelfand, M. (1981). Ukama: Reflections on Shona and Western Cultures in Zimbabwe, Gweru: Mambo Press.

Frazer, J. (1910). Totemism and Exogamy, Bungay: Suffolk. 
Gluckman, M. (1965). The Politics, Law and Ritual in Tribal Society, London: Claredon Press

Howells, W. (1949). The Heathens: Primitive Man and His Religion, London: Victor Gollancz,

Jacobs, J. U. (1990). 'Naming a Crisis' Nomina Africana 4(1).

Koopman, A. (2002) Zulu clan names, Scottville: University of Natal Press.

Makondo, L. (2008). 'Ethnicity and Matriarchal Protest: A case of Dialoguing Shona Personal Names' Names: A Journal of Onomastics, Vol 56(1), Maney Publishing.

Mashasha, F (undated) 'The Early History of the Gutu Chiefdom' University of Zimbabwe, Department of History.

Mtetwa, R. G. M. (1976). 'The Political and Economic History of the Duma People of South Eastern Rhodesia from the Early 18thCentury to 1945' (Unpublished PhD Thesis), Harare: University of Zimbabwe.

Pfukwa, C. (1998). 'Their own Godparents' Zimbabwean Review 4(3).

Pfukwa, C. (2007). The Function and Significance of War Names in the Zimbabwean Conflict 1966-1979, Pretoria: University of South Africa.

Pikirayi, I. (1993). The Archaeological Identity of the Mutapa State: Towards an Historical Archaeology of Northern Zimbabwe. Archaeological Psalinsis, Uppsala.

Pongweni, A. J. C. (1989). What is in a name? A study of Nomenclature, Gweru: Mambo Press.

Ranger, T. (1987). Religion, Development and African Christian Identity, Uppsala: Scandinavian Institute of African Languages.

Tatira, L (2004) 'Beyond the dog name: A silent dialogue among the Shona people' Journal of Folklore Research, Vol.41.

Van Langendock, W. F. (2001). 'Bynames within the personal names systems' Nomina Africana 15 (1). 